\title{
Gas exchange alteration caused by water deficit during the bean reproductive stage
}

\author{
Lauricio Endres', José L. de Souza ${ }^{2}$, ledo Teodoro', Paula M. G. Marroquim ${ }^{3}$, Claudiana M. dos Santos ${ }^{4}$ \& José E. D. de Brito
}

\begin{abstract}
The purpose of the present study was to analyze gas exchanges in leaves and the parameters of productivity of beans (Phaseolus vulgaris, L.) submitted to two water deficiency periods during which three water regimes were employed: $\mathrm{W}_{1}\left(1,0 \mathrm{ET}_{0}\right.$ during the entire plant cycle); $\mathrm{W}_{2}\left(1,0 \mathrm{ET}_{0}\right.$ up to the flowering period and irrigation interruption from the 37 to the $51^{\text {st }}$ day following sowing, and $\mathrm{W}_{3}$ (in addition to the reproductive phase, water deficit was also applied during the vegetative stage). Photosynthesis was one of the main physiological factors affected by water deficit. This was not only caused by the stomata closure, but also by carboxilation reduction due to metabolic damage. This effect was, however, offset $24 \mathrm{~h}$ after rehydration. During flowering, the water deficit caused crop productivity to drop significantly, reducing the number of pods and the number of seeds per pod, independently of the water deficit during the vegetative stage. The weight of 100 seeds however, was the same regardless of treatment. These results suggest that the water deficit caused the reduction of photo-assimilates, which affected grain productivity. Nevertheless, once properly formed, seeds developed totally; a strategy of the plant to produce less seeds under stress, but viable to perpetuate the species.
\end{abstract}

Key words: photosynthesis, transpiration, Phaseolus vulgaris L.

\section{Alterações das trocas gasosas na fase reprodutiva e produtividade do feijão sob déficit hídrico}

\section{RESUMO}

Neste trabalho, se analisaram as trocas gasosas das folhas e parâmetros de produtividade de feijão (Phaseolus vulgaris, L.) submetido a dois períodos de deficiência hídrica e se empregaram três regimes hídricos, a saber: $\mathrm{W}_{1}(1,0 \mathrm{ET}$ d durante todo o ciclo da cultura); $W_{2}$ (1,0 ET até a floração e suspensão da irrigação do 37 ao $51^{\circ}$ dia após a semeadura (DAS), correspondendo à fase de floração) e $W_{3}$ (além da fase reprodutiva também se aplicou um déficit hídrico durante a fase vegetativa). A fotossíntese foi um dos principais fatores fisiológicos afetados pelo déficit hídrico devido não só ao fechamento estomático, mas, também, à redução da eficiência de carboxilação, resultante de um dano metabólico; este efeito, contudo, foi neutralizado 24 h após reidratação. Durante a floração o déficit hídrico causou redução sensível da produtividade da cultura, com redução também do número de vagens e número de sementes por vagem, independentemente do déficit durante a fase vegetativa, porém a massa de 100 sementes não se alterou em nenhum dos regimes; esses resultados sugerem que o déficit hídrico leva a uma redução dos fotoassimilados prejudicando a produção final; no entanto, uma vez formada, a semente se desenvolve plenamente, sendo esta uma estratégia da planta em produzir poucas sementes, mas viáveis para perpetuar a espécie, mesmo sob condições de estresse.

Palavras-chave: fotossíntese, transpiração, Phaseolus vulgaris L.

\footnotetext{
${ }^{1}$ Centro de Ciências Agrárias/UFAL. BR 104 N, km 85, CEP 57100-000, Rio Largo, AL. Telephone (82) 3261-1351. E-mail: endres@pq.cnpq.br; iteodoro@ceca.ufal.br ${ }^{2}$ Centro de Ciências Exatas e Naturais/UFAL. Campus A. C. Simões, BR 104 - Norte, Km 97, Cidade Universitária, CEP 57072-970, Maceió, AL. Telephone (82) 3214-1360. E-mail: jls@ccen.ufal.br

Bióloga, UFAL. E-mail: pmgmarroquim@hotmail.com
} 


\section{INTRODUCTION}

In semi-arid areas, where the deficit of pluvial precipitation is one of the main factors limiting agricultural production, efforts have been directed towards the development of productive systems that has been well accepted by the local population (Smolikowski et al., 2001). In some areas of the Northeastern Brazil, bean is one of the main subsistence crops for small farmers. Most of the bean production in the Northeastern Brazil is accomplished under severe water deficiency, causing staggering losses at some time of the crop cycle. This problem is still greater for those small farmers who have no means to set up irrigation systems for their crops. To make matters worse, some modern varieties of beans have been less tolerant to drought stress (Singh, 2001).

The influence of meteorological conditions on human activities and on the environment as a whole is a fact well known by most researchers (Monteith \& Unsworth, 1990; Rosenberg et al., 1983; Pereira et al., 1997). A far more comprehensive study of environmental issues, mainly those involving interactions between the atmosphere and the socalled surface processes (vegetation, for instance), constitutes basic prerequisites for further rational exploration of the region's natural resources. This will help subsidize researches in areas such as: meteorology, farming, engineering, energy and environmental sciences, among others.

Photosynthesis is perhaps one of the parameters most affected by environmental conditions (Oren et al., 1999; He et al., 2009; Zheng et al., 2009). Water deficiency limits photosynthesis because of the restriction of $\mathrm{CO}_{2}$ diffusion from the external environment to the carboxilation site in chloroplast (Lawlor \& Cornic, 2002; Chaves et al., 2003). Severe drought stress can also induce biochemical damage by reducing Calvin Cycle activity (Lawlor \& Cornic, 2002).

Stomata conductance is one of the main factors affecting the photosynthesis of plants (Medrano et al., 2002). In most cases, the stomata close themselves in response to drought before any change in water potential or in leaf water content occurs (Socias et al., 1997). The stomata may also close when the vapor pressure deficit between the leaves and the air increases (Oren et al., 1999). The $\mathrm{CO}_{2}$ and water vapor are exchanged through the same stomata pores; consequently, stomata conductance becomes most significant both through photosynthesis determination and through transpiration.

Alterations that take place in the environmental conditions affect photosynthetic activities, altering, as a result, crop productivity (Fleisher et al., 2008; Reynolds et al., 2007).
Consequently, where water availability is concerned, knowledge about the relation between photosynthesis, plant growth and productivity is required in order to better define agricultural growth standards for the adoption of self-sustainable production procedures.

The present work proposes an analysis of photosynthesis and transpiration in leaf and the examination of bean productivity under water deficiency during flowering.

\section{MATERIAL AND METHODS}

An experiment with bean (Phaseolus vulgaris L.) variety Pérola (seeds made available by the EMBRAPA) was conducted in the municipality of Rio Largo, AL ( $9^{\circ} 28^{\prime} 02^{\prime \prime} \mathrm{S}$; $35^{\circ} 49^{\prime} 43^{\prime}$ W; $127 \mathrm{~m}$ ) during the period from December 2004 to March 2005. The experimental design was entirely randomized and consisted of eight replications with plot size of $2.5 \mathrm{~m}$ wide and $5 \mathrm{~m}$ long at a distance of $0.5 \mathrm{~m}$ between lines with 15 seeds per linear meter, resulting in a total of 240,000 plants ha-1.

The soil presented $\mathrm{pH}\left(\mathrm{H}_{2} \mathrm{O}\right)$ 5.9; consequently, no liming was required, and basal dose of fertilizers was applied based on the chemical analysis of the soil (Table 1) according to EMBRAPA (1997) and consisted of $450 \mathrm{~kg} \mathrm{ha}^{-1}$ of the formula 04-10-13 (totalizing $100 \mathrm{~kg}$ of ammonium sulphate, $250 \mathrm{~kg}$ of simple superphosphate, and $100 \mathrm{~kg}$ of potassium chloride per hectare). Twenty-five days after sowing $100 \mathrm{~kg} \mathrm{ha}^{-1}$ of urea was used, at one single time, as top dressing.

The climate of the region is hot and moist $\left(\mathrm{B}_{1}\right)$, megathermal (A') with moderate water deficiency in the summer along with water surplus in the winter $\left(\mathrm{w}_{2}\right)$ according to Thornthwaite-Mather classification (Carvalho, 2003). Mean air temperature varies from $19{ }^{\circ} \mathrm{C}$ (August) to $32{ }^{\circ} \mathrm{C}$ (January), with an annual mean of $25^{\circ} \mathrm{C}$; the mean monthly relative humidity is $70 \%$, and the mean annual rainfall being $1,818 \mathrm{~mm}$ with total minimum values of $41 \mathrm{~mm}$ in December and maximum values of $294 \mathrm{~mm}$ in July. Annual rainfall concentrates (61\%) in April-July period. The months between October-February have a mean rainfall of $300 \mathrm{~mm}$

Table 1. Chemical composition of soil of $0.20 \mathrm{~cm}$ of the experimental site

\begin{tabular}{|c|c|c|c|c|c|c|c|c|c|c|}
\hline \multirow{2}{*}{$\underset{\mathrm{H}_{2} \mathrm{O}}{\mathrm{pH}}$} & $\mathbf{P}$ & $\mathbf{K}^{+}$ & $\mathrm{H}+\mathrm{Al}$ & $\mathrm{Al}^{3+}$ & $\mathrm{Ca}^{2+}$ & $\mathrm{Mg}^{2+}$ & CTC $_{\text {total }}$ & V & M & MO \\
\hline & \multicolumn{2}{|c|}{$\mathrm{mg} \mathrm{dm^{-3 }}$} & \multicolumn{5}{|c|}{$\mathrm{cmol}_{\mathrm{G}} \mathrm{dm}^{-3}$} & \multicolumn{3}{|c|}{$\%$} \\
\hline 5.9 & 17 & 45 & 3.5 & 0.05 & 2.5 & 2.1 & 8.5 & 54.8 & 1.1 & 2.15 \\
\hline
\end{tabular}

Analysis carried out by the Central Analítica Ltda, Maceió, AL

Table 2. The physical characteristics of soil of the experimental site

\begin{tabular}{|c|c|c|c|c|c|c|c|c|c|c|}
\hline \multicolumn{2}{|c|}{ Horizon } & \multicolumn{4}{|c|}{ Granulemetry composition (\%) } & \multirow{2}{*}{$\begin{array}{c}\text { Clay } \\
\text { dispersed in } \\
\text { water (\%) }\end{array}$} & \multirow{2}{*}{$\begin{array}{c}\text { Degre of } \\
\text { flocculation } \\
(\%)\end{array}$} & \multirow{2}{*}{$\begin{array}{l}\text { Relation } \\
\text { Silt/Clay }\end{array}$} & \multicolumn{2}{|c|}{ Density - $\mathrm{kg} \mathrm{dm}^{-3}$} \\
\hline Identification & Depth - cm & GS & FS & Silt & Clay & & & & Particle & Soil \\
\hline Ap1 & $0-11$ & 51 & 10 & 7 & 32 & 13 & 59 & 0.32 & 2.60 & 1.37 \\
\hline Ap2 & $11-22$ & 47 & 17 & 5 & 31 & 0 & 100 & 0.16 & 2.66 & 1.46 \\
\hline$A B$ & $22-47$ & 43 & 14 & 6 & 37 & 0 & 100 & 0.16 & 2.71 & 1.60 \\
\hline Bw1 & $47-82$ & 32 & 12 & 2 & 54 & 21 & 61 & 0.04 & 2.60 & 1.58 \\
\hline Bw2 & $82-153$ & 33 & 13 & 1 & 53 & 33 & 38 & 0.02 & 2.60 & 1.50 \\
\hline Bw3 & $153-200+$ & 22 & 10 & 15 & 53 & 14 & 74 & 0.28 & 2.60 & 1.40 \\
\hline
\end{tabular}

GS Gross sand; FS Fine sand 
and an evaporation rate of $972 \mathrm{~mm}$ (Souza et al., 2005).

The soil of area studied is classified as Cohesive Argisolic Yellow Latosol (Table 2). The water retention curve of the soil under analysis was obtained by means of Richards' method (Richards, 1948) at the Laboratory of CECA/UFAL, and revealed the available water capacity (AWC) of $24 \mathrm{~mm}$ in a depth of $0.30 \mathrm{~m}$.

The irrigation method employed was that of conventional aspersion in a $12 \times 12 \mathrm{~m}$ spatial intervals. The service pressure (Ps) and the average discharge (q) of aspersers was found to be $1.8 \mathrm{kPa}$ and $1.10 \mathrm{~m}^{3} \mathrm{~h}^{-1}$ respectively, uniformity coefficient of application of irrigation water application was $85 \%$, as determined by means of mini-pluviometers. A twofixed-day interval was set up to apply irrigation. The pressure of the irrigation system and discharge were monitored by means of manometers and hydrometers, respectively.

The reference evapotranspiration $\left(\mathrm{ET}_{\mathrm{o}}\right)$, as determined by the Penman-Monteith model following the recommendation of FAO-56 (Allen et al., 1998) was determined and used as the main criteria in the water application. The climatic elements needed to determine the $\mathrm{ET}_{\mathrm{o}}$ estimates were obtained from an automatic meteorological station (Micrologger - 21XL, Campbell Scientific, Logan, Utah). The soil water measurements were obtained by automatic water content reflectometers (CS616 Water Content Reflectometers, Campbell Scientific, Inc.).

Treatments consisted of three levels of irrigation: $\mathrm{W}_{1}$ (water application equivalent to $1,0 \mathrm{ET}_{\mathrm{o}}$ during the whole crop cycle); $\mathrm{W}_{2}$ (water application equivalent to $1,0 \mathrm{ET}_{\mathrm{o}}$ up to the flowering period and irrigation interruption from the $37^{\text {th }}$ to $51^{\text {st }}$ day after sowing (DAS) which corresponded to the flowering phase; and $\mathrm{W}_{3}\left(1,0 \mathrm{ET}_{0}\right.$ up to the $12^{\text {th }} \mathrm{DAS}$ and $0.5 \mathrm{ET}_{0}$ from the $15^{\text {th }}$ to $28^{\text {th }}$ day DAS, irrigation disruption between the $29^{\text {th }}$ and $36^{\text {th }}$ DAS, during the vegetative phase; application of $15.6 \mathrm{~mm}$ on the $36^{\text {th }}$ DAS to reach field capacity and again the irrigation was suspended from the $37^{\text {th }}$ to $51^{\text {st }}$ DAS during flowering. During the period of irrigation interruption, rainfall was negligible, but from the $51^{\text {st }} \mathrm{DAS}$, water application was equivalent to $1.0 \mathrm{ET}_{\mathrm{o}}$ in all three treatments. Treatment $\mathrm{W}_{1}$ corresponded to the control without water deficit; $\mathrm{W}_{2}$, the water deficit was employed only during flowering; $W_{3}$, water deficit was applied during the vegetative and reproductive phases. Both the stages and phenological phases of bean crop were determined in accordance with a phenological scale of Fernandez et al. 1982 (Vieira 1991). The occurrence of phenological events was taken into account only when 50\% of the plants attained determined stage.

Gas exchange measurements were made on plants located in the central part of the plot, and on fully expanded leaves, at 8:00 to 10:00 am by using a portable infrared $\mathrm{CO}_{2}$ analyzer (IRGA), ADC, Lei model (Hoddesdon, UK) on the $35^{\text {th }}, 37^{\text {th }}, 42^{\text {nd }} .45^{\text {th }}$ and $50^{\text {th }}$ DAS during the crop productive phase, in which irrigation was suspended in $\mathrm{W}_{2}$ and $\mathrm{W}_{3}$ treatments (irrigation was interrupted on the $36^{\text {th }}$ DAS). The following parameters were evaluated: photosynthesis rate (A), transpiration rate $(\mathrm{E})$, internal $\mathrm{CO}_{2}$ concentration $(\mathrm{Ci})$, ambient $\mathrm{CO}_{2}$ concentration $(\mathrm{Ca})$ and the instantaneous efficiency of carboxilation given by the relation $\mathrm{A} / \mathrm{Ci}$.

In each experimental plot, harvesting was carried out on the $72^{\text {nd }}$ DAS in $4.0 \mathrm{~m}$ of central row, leaving a boarder of $0.5 \mathrm{~m}$ on each side, determining the mass of 100 seeds, number of pods per plant, number of seeds per pod and productivity.

The statistical design was completely randomized and consisted of 8 replications. Three sub-samples were utilized to carry out gas exchange measurements; and to obtain the parameters of production, one sample was taken. The data were compared by Turkey test at 5\% probability.

\section{RESULTS AND DISCUSSION}

Plant water status had a significant impact on gas exchange in leaves. Plants in $\mathrm{W}_{3}$ treatment, on the $35^{\text {th }} \mathrm{DAS}$, were under water deficiency. This affected enormously stomata conductance (Figure 1A), transpiration (Figure 1B) and photosynthesis (Figure 1C), with reductions of 96, 83 and $85 \%$ in relation to control, respectively. On the $36^{\text {th }}$ day, all treatments were irrigated with a $15.6 \mathrm{~mm}$ water in order to achieve field capacity. Twenty-four hours later, the plants which were submitted to stress $\left(\mathrm{W}_{3}\right)$ had already recovered their water status and their photosynthesis capacity, as verified after measuring the stomata conductance and gas exchange. Bean is, therefore, a crop that responds well to irrigation when submitted to moderate water deficit. Similar results with bean (cv. Yamashirokurosanndosaitou) were obtained by Miyashita et al. (2005) who observed complete recovery of photosynthetic rate two days following rehydration after moderate water deficit; however, under severe water deficit total recovery did not occur.

Considering the period between the $37^{\text {th }}$ and the $42^{\text {nd }}$ DAS, the plants submitted to severe water deficit $\left(\mathrm{W}_{3}\right)$ showed larger reductions in their stomata conductance (Figure 1A), gas exchange (Figures $1 \mathrm{~B}$ and $1 \mathrm{C}$ ) and an increase in leaf temperature (Figure $1 \mathrm{~F}$ ) compared to the other treatments. Plants under treatment $\mathrm{W}_{3}$ also went through a water deficit during vegetative phase, which may have contributed to a more immediate response to stress. The $\mathrm{W}_{2}$, plants, for which irrigation was suspended only on the $37^{\text {th }}$ DAS, started to suffer from water deficiency on the $42^{\text {nd }}$ DAS.

A decrease in photosynthetic activity as a result of water deficiency may be due to the impairment of the $\mathrm{CO}_{2}$ entry through the stomata, or it may be due to direct damages over the photosynthetic metabolism. On beans submitted to experimental trial conditions, in spite of the existence of restriction on photosynthesis (Figure 1C) because of a decrease in the internal concentration of $\mathrm{CO}_{2}$ (Figure 1D) caused by reduction of stomata conductance (Figure 1A), there also occurred some metabolic damage which was confirmed by decrease in carboxilation rate (Figure 1E). According to Miyashita et al. (2005), under severe water deficit, it is impossible for the bean to recover its full photosynthetic activities after rehydration because of irreversible metabolic damage in chloroplast.

Transpiration restriction caused by water deficit (Figure 1F) caused a rise in canopy temperature (Figure $1 \mathrm{~F}$ ). This may have contributed towards the development of thermal stress of the leaves, which may have decreased further the photosynthetic efficiency (Figure 1C) causing direct damage in the 
A.

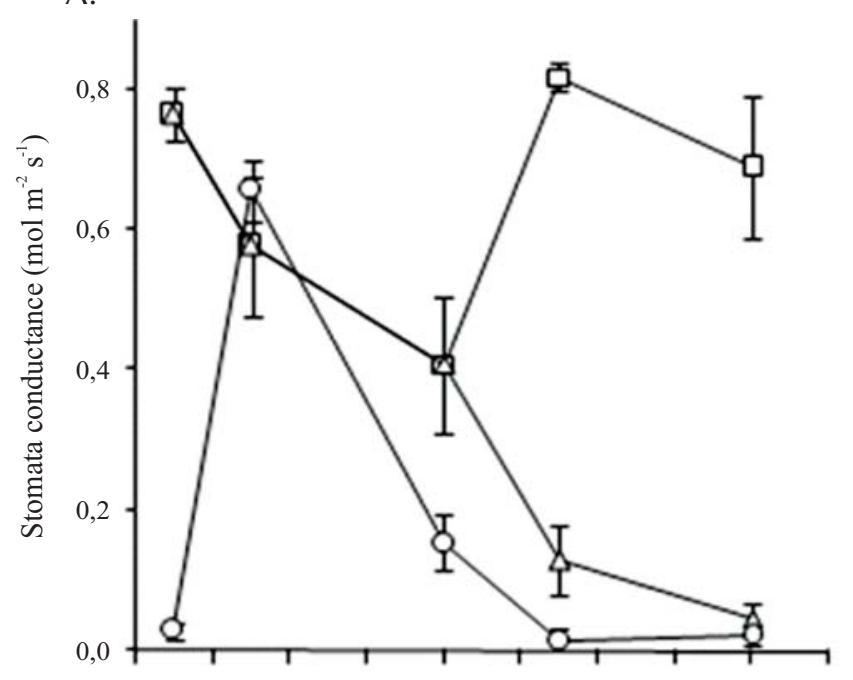

B.

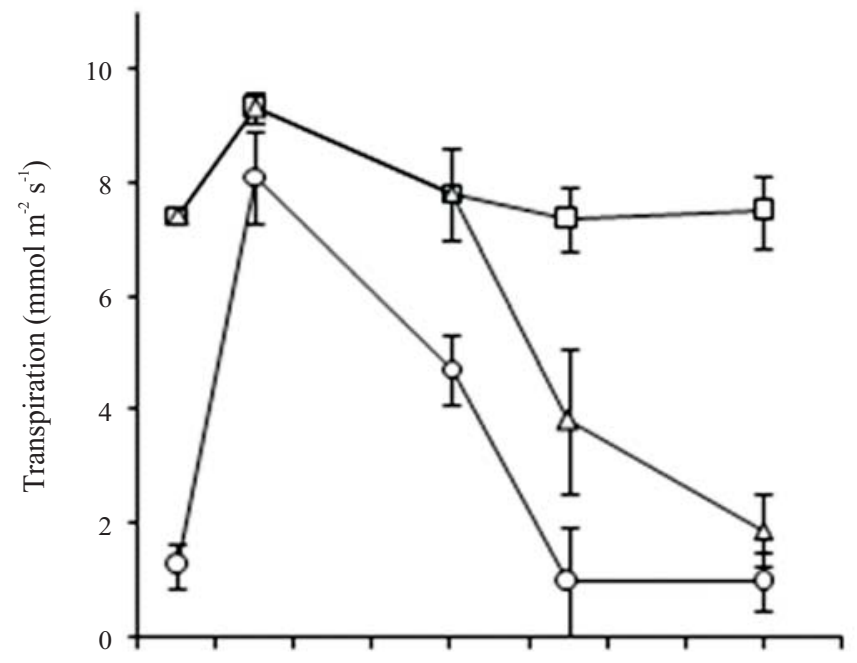

C.

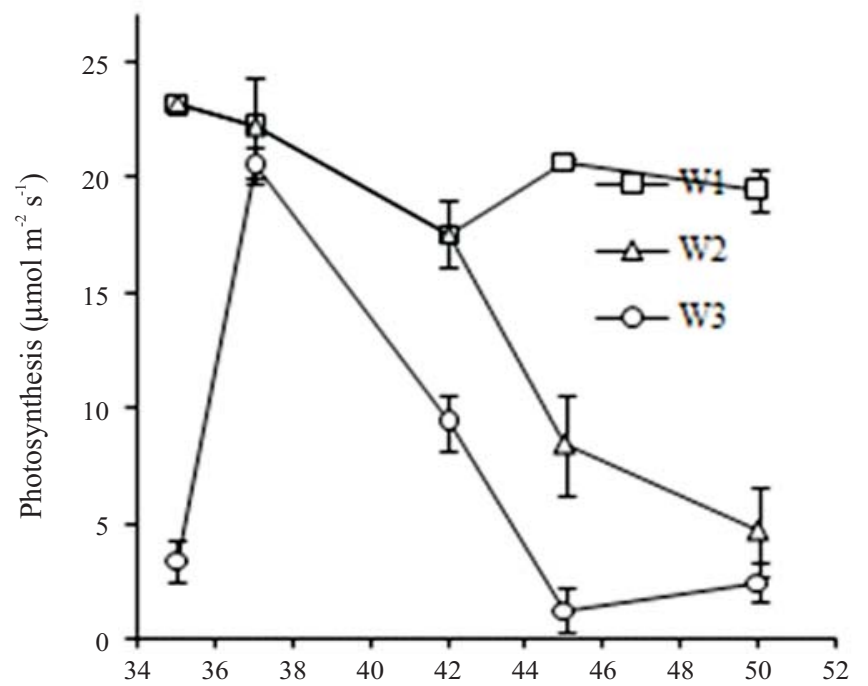

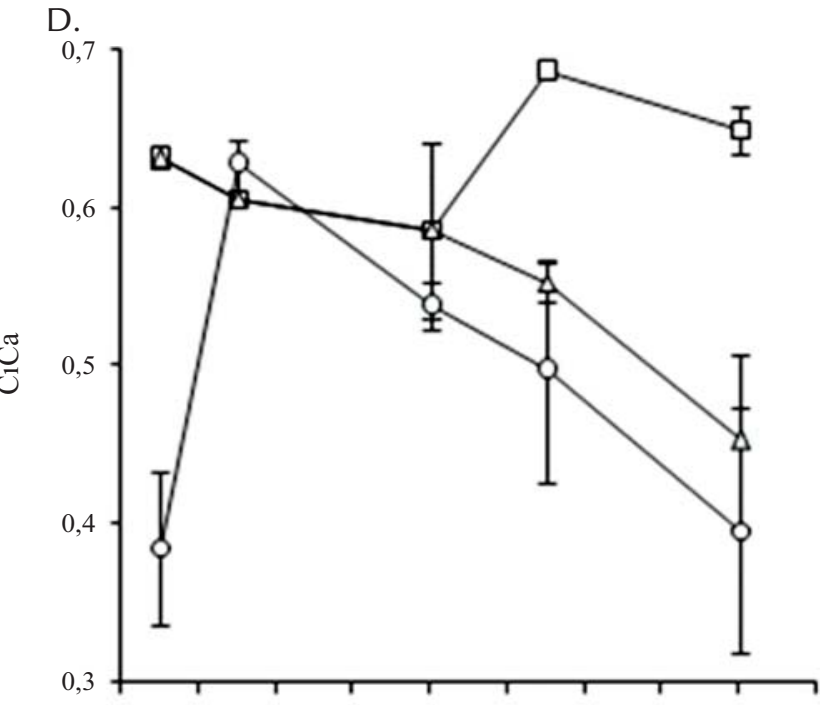

E.

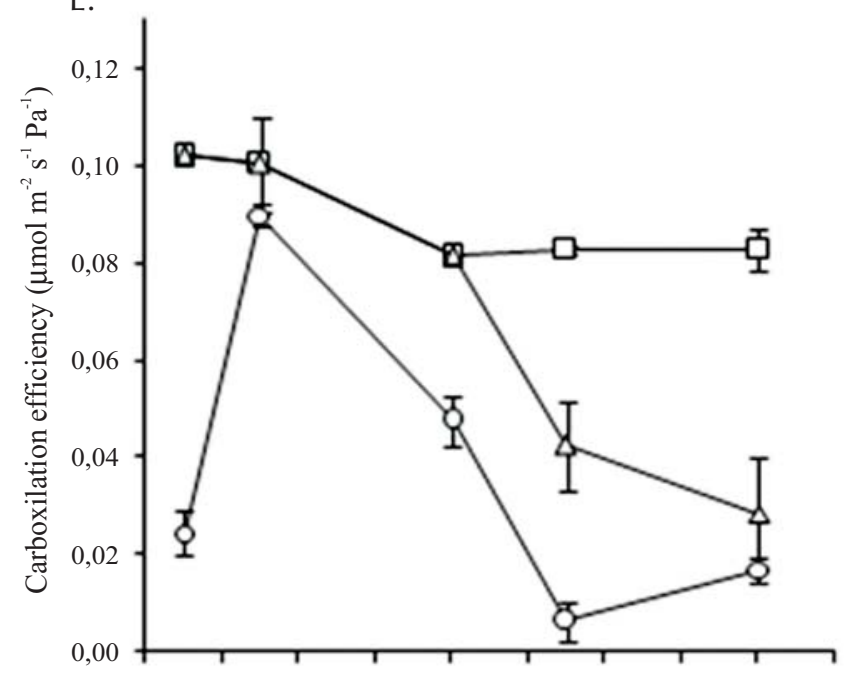

F.

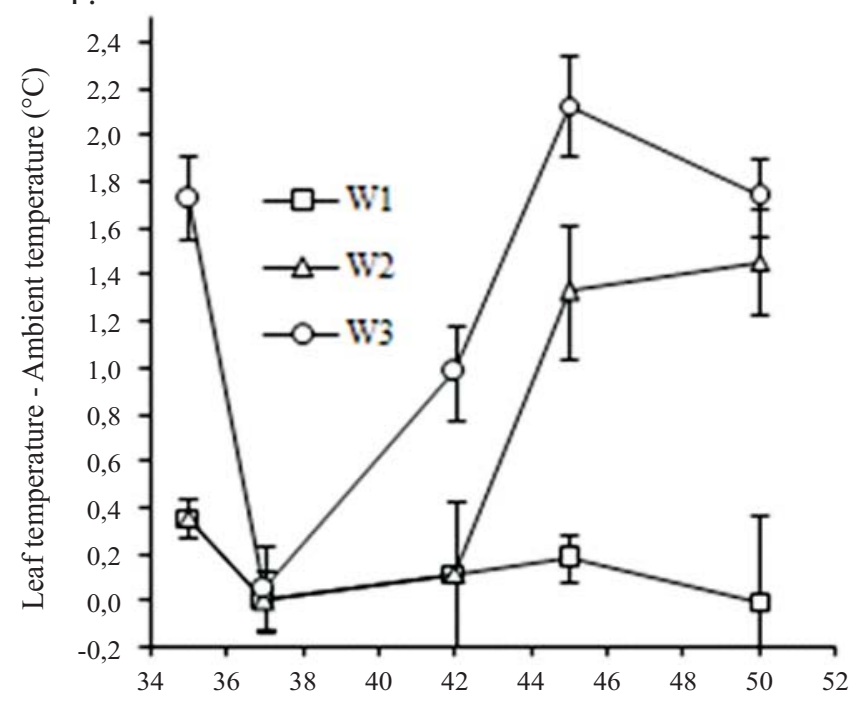

Days after sowing

Observation: $\mathrm{W}_{1}$ (water application equivalent to $1,0 \mathrm{ET}_{0}$ during the whole crop cycle); $\mathrm{W}_{2}$ (water application equivalent to $1.0 \mathrm{ET}_{0}$ up to flowering and irrigation interruption from the $37^{\text {th }}$ to the $51^{\text {st }}$ day after sowing (DAS), corresponding to the flowering period); and $\mathrm{W}_{3}$ (water application equivalent to $1.0 \mathrm{ET}_{0}$ up to the $12^{\text {th }} \mathrm{DAS}$ and $0.5 \mathrm{ET}_{0}$ from the $15^{\text {th }}$ to the $28^{\text {th }} \mathrm{DAS}$, irrigation interruption between the $29^{\text {th }}$ and $36^{\text {th }}$ DAS during the vegetative phase; $15.6 \mathrm{~mm}$ on the $36^{\text {th }}$ DAS to attain field capacity and again irrigation interruption from the $37^{\text {th }}$ to the $51^{\text {st }}$ DAS during the flowering period).

Figure 1. Stomata conductance $(A)$, transpiration $(B)$, net photosynthesis $(C)$, maximum internal/external concentration of $\mathrm{CO}_{2}(\mathrm{Ci} / \mathrm{Ca})(\mathrm{D})$, instantaneous carboxilation efficiency $(\mathrm{A} / \mathrm{Ci})(\mathrm{E})$ and $\mathrm{T}_{\text {leaf }}-\mathrm{T}_{\text {air }}(\mathrm{F})$ of bean plants cv. Pérola submitted to different water regimes 
photosynthetic metabolism (Figure 1E). Maintenance of leaf temperature - either equal or slightly superior to the air temperature - attests for the plant's cooling capacity through transpiration so as to keep itself protected against higher thermal oscillations (Oliveira et al., 2005).

It is worth noticing that the size of the seeds did not decrease on account of water deficit (Figure 2A); on the other hand, the number of pods decreased (Figure 1B) together with the number of seeds per pod (Figure 2C). Similar results were observed in bean by Lizana et al. (2006). Considering the evolution aspect of plants, one can say that it would be far more interesting for plants to produce fewer seeds under unfavorable conditions, but with enough reserves to sustain new seedling growth to guarantee the species preservation. Should this strategy prove true, yield will fall

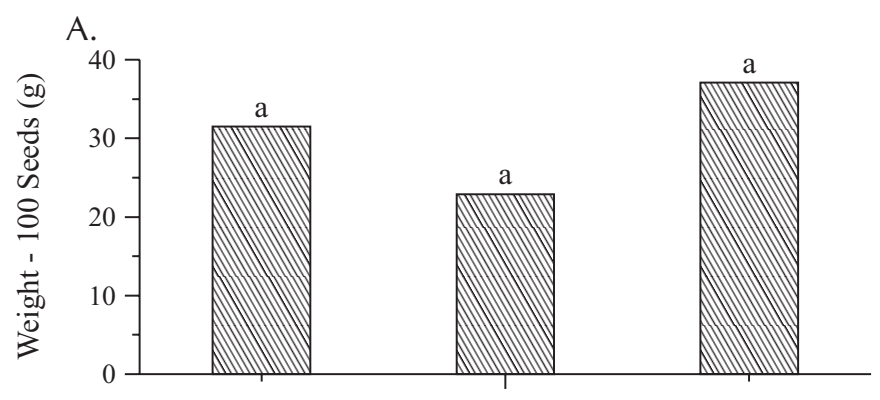

B.

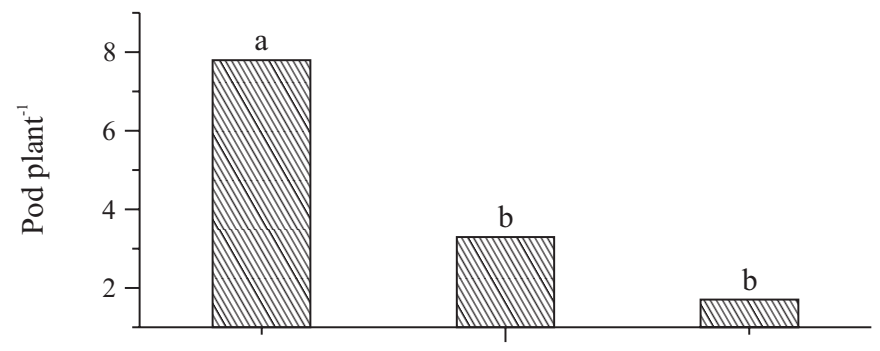

C.

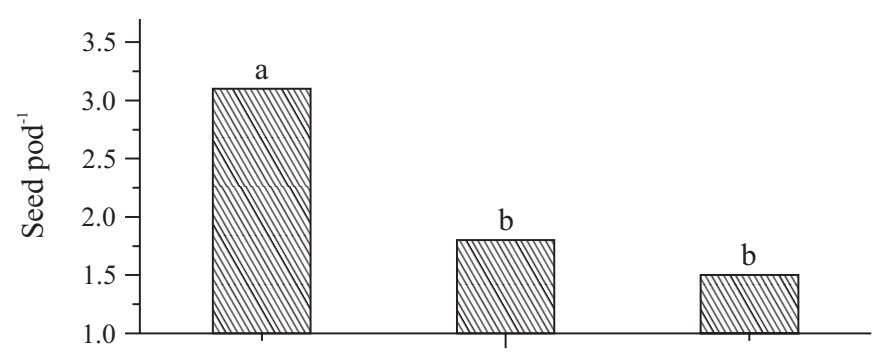

D.

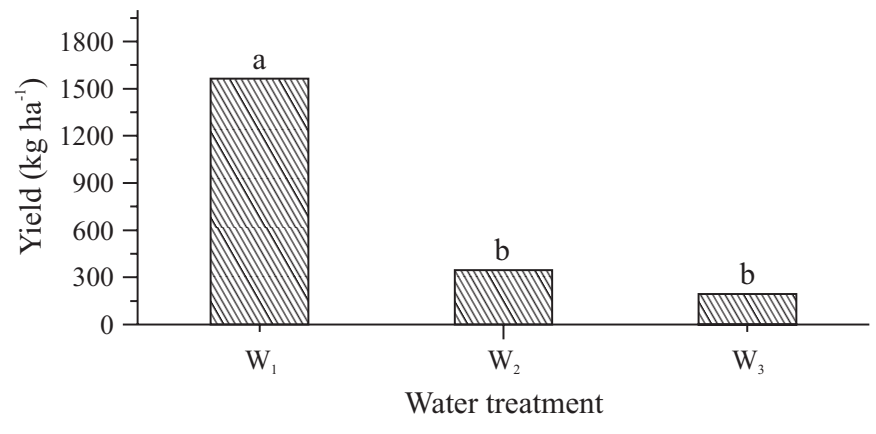

Figure 2. Weight of 100 seeds (A), pods per plant (B), seeds per pod (C) and bean productivity (D) cv Pérola submitted to different water regimes (details of the water regime may be seen in Figure 1 legend) drastically (Figure 2D), mainly because the water deficit may have affected $\mathrm{CO}_{2}$ assimilation with direct impact on flower abscission, one of the predominant factors of production (Clements \& Atkins, 2001). According to Karam et al. (2005), the bean reproductive phase is most vulnerable to water deficit in the soil. Any reduction concerning normal water condition will reflect on productivity, making it drop; for instance, reduction in photosynthesis during pollination causes embryos to abort, causing an inevitable reduction in yields (Kramer \& Boyer, 1995). This may be due to the fact that there were no significant differences between productivity parameters from the treatments $\mathrm{W}_{2}$ and $\mathrm{W}_{3}$, notwithstanding the fact that this last had suffered water deficit during reproductive period, which shows again that an adequate availability of soil water is extremely vital for grain production, and that a lack of photoassimilation may have a serious impact on the whole process.

Studies have demonstrated that many crops can resist water deficiencies with no damage to plant growth or to any other physiological processes (Turner, 1990). This, however, is not the case of bean crop, especially in its reproductive phase. Water availability is vital for bean production. Water deficit damages the plant's photosynthetic activity by closing the stomata and altering the photosynthetic metabolism. In case this deficit occurs during the reproductive phase, the outcomes of such effects are most disastrous for the plant, causing not only the abortion of embryos, but also the loss of leaf and fruit. The final result is fewer seeds per pod and drastic fall in productivity.

\section{CONCLUSIONS}

1. Photosynthesis was one of the main physiological parameter affected by water deficit.

2. Photosynthesis reduction aggravated by water deficit was caused by stomata closure and by reducntion in carboxilation efficiency.

3. Water deficit during flowering caused moderate reduction in the crop productivity due to a reduction in the number of pods and in the number of seeds per pod.

4. The weight of 100 seeds was not affected by water deficit.

\section{ACKNOWLEDGMENTS}

The authors wish to express their gratefulness to FAPEAL (Fundação de Amparo a Pesuisa do Estado de Alagoas) and to the CTHidro-CNPq for their invaluable support by granting scientific initiation scholarships, and to EMBRAPA for the supply of seeds for the experiments.

\section{LITERATURE CITED}

Allen, R. G; Pereira, L. S.; Raes, D.; Smith, M. Crop evapotranspiration: Guidelines for computing crop water requirements. Rome: FAO, 1998. 300p. FAO. Irrigation and Drainage Papers, 56. 
Carvalho, O. M. Classificação e caracterização físico-hídrica de solos de Rio Largo, AL, cultivados com cana-de-açúcar. Rio Largo: CECA/UFAL, 2003. 74p. Dissertação Mestrado

Chaves, M. M.; Maroco. J. P.; Pereira, J. S. Understanding plant responses to drought - from genes to the whole plant. Functional Plant Biology, v.30, p.239-264, 2003.

Clements, J.; Atkins, C. Characterization of non-abscission mutant I Lupinus angustifolius. I. Genetic and structural aspects. American Journal of Botany, v.88, p.31-42, 2001.

EMBRAPA - Empresa Brasileira de Pesquisa Agropecuária. Recomendações técnicas para o cultivo do feijão. Centro Nacional de Pesquisa de Arroz e Feijão, Goiania: Embrapa CNPAF, 1997. 32p.

Fernández, F.; Gepts, P.; López, G. M. Etapas de desarrolo de la planta de frijol común. Cali: Centro Internacional de Agricultura Tropical, 1982. 26p.

Fleisher, D. H.; Timlin, D. J.; Reddy, V. R. Elevated carbon dioxide and water stress effects on potato canopy gas exchange, water use, and productivity. Agriculture and Forest Meteorology, v.148, p.1109-1122, 2008.

He, Y.; Zhu, Z.; Yang, J.; Ni, X.; Zhu, B. Grafting increases the salt tolerance of tomato by improvement of photosynthesis and enhancement of antioxidant enzymes activity. Environmental and Experimental Botany, in press, doi:10.1016/ j.envexpbot.2009. 2 Jul. 2009.

Karam, F.; Masaad, R.; Sfeir, T.; Mounzer, O.; Rouphael, Y. Evapotranspiration and seed yield of field grown soybean under deficit irrigation conditions. Agriculture Water Management, v.75, p.226-244, 2005.

Kramer, P. J.; Boyer, J. S. Water relations of plants and soils. San Diego: Academic Press, 1995. 495p.

Lawlor, D. W.; Cornic, G. Photosynthetic carbon assimilation and associated metabolism in relation to water deficits in higher plants. Plant, Cell and Environment, v.25, p.275-294, 2002.

Lizana, C.; Wentworth, M.; Martinez, J. P.; Villegas, D.; Meneses, R.; Murchie, E.; Pastenes, C.; Lercari, B., Vernieri, P.; Horton, P.; Pinto, M. Differential adaptation of two varieties of common bean to abiotic stress. I. Effects of drought on yield and photosynthesis. Journal of Experimental Botany, v.57, p.685-697, 2006.

Medrano, H.; Escalona, J. M.; Bota, J.; Gulias, J.; Flexas, J. Regulation of photosynthesis of C-3 plants in response to progressive drought: Stomatal conductance as a reference parameter. Annals of Botany, v.89, p.895-905, 2002.

Miyashita, K.; Tanakamaru, S.; Maitani, T.; Kimura, K. Recovery responses of photosynthesis, transpiration, and stomatal conductance in kidney bean following drought stress. Environmental and Experimental Botany, v.53, p.205-214, 2005.
Monteith, J. L.; Unsworth, M. H. Principles of environmental physics. 2.ed. London: E. Arnold, 1990. 291p.

Oliveira, A. D.; Fernandes, E. J.; Rodrigues, T. J. D. Condutância estomática como indicador de estresse hídrico em feijão. Engenharia Agrícola, v.25, n.1, p.86-95, 2005.

Oren, R.; Sperry, J. S.; Katul, G. G.; Pataki, D. E.; Ewers, B. E.; Phillips, N.; Schafer, K. V. R. Survey and synthesis of intra- and interspecific variantion in stomatal sensitivity to vapour pressure deficit. Plant, Cell and Environment, v.22, p.1515-1526, 1999.

Pereira, A. R.; Villa Nova, N. A.; Sediyama, G. C. Evapotranpiração. Piracicaba: FEALQ, 1997. 183p.

Reynolds, P. E.; Simpson, J.A.; Thevathasan, N. V.; Gordon, A. M. Effects of tree competition on corn and soybean photosynthesis, growth, and yield in a temperate tree-based agroforestry intercropping system in southern Ontario, Canada. Ecological Engineering, v.29, p.362-371, 2007.

Richards, L. A. Porous plate apparatus for measuring moisture retention and transmission by soil. Soil Science v.66, p.105-110, 1948.

Rosenberg, N. J.; Blad, B. L.; Verma, S. B. Microclimate: The biological environment. 2.ed. New York: John Wiley, 1983. 495p.

Singh, S. P. Broadening the genetic base of common bean cultivars: a review. Crop Science, v.41, p.1659-1675, 2001.

Smolikowski, B.; Puig, H.; Roose, E. Influence of soil protection techniques on runoff, erosion and plant production on semi-arid hillsides of Cabo Verde. Agriculture, Ecosystems and Environment, v.87, p.67-80, 2001.

Socias, X.; Correia, M. J.; Chaves, M. M.; Medrano, H. The role of abscisic acid and water relations in drought responses of subterranean clover. Journal Experimental Botany, v.48, p. 1281-1288, 1997.

Souza, J. L.; Nicácio, R. M.; Moura, M. A. L. Global solar radiation measurements in Maceió, Brazil. Renewable Energy Reading, v.30, p.1203-1220, 2005.

Turner, N. C. Plant water relations and irrigation management. Agriculture Water Management, v.17, p.59-73, 1990.

Vieira, C. Influência das épocas de plantio sobre as etapas de desenvolvimento do feijoeiro (Fhaseolus vulgaris L.) Revista Ceres, v.38, p.439-43,1991.

Zheng, C; Jiang, D.; Liu, F.; Dai, T.; Jing, Q.; Cao, W. Effects of salt and waterlogging stresses and their combination on leaf photosynthesis, chloroplast ATP synthesis, and antioxidant capacity in wheat. Plant Science, v.176, p.575-582, 2009. 